\title{
Nuclear oxysterol receptors, LXRs, are involved in the maintenance of mouse caput epididymidis structure and functions
}

\author{
J-M Frenoux*, P Vernet*, D H Volle ${ }^{1}$, A Britan, F Saez, A Kocer, J Henry-Berger1, \\ D J Mangelsdorf ${ }^{2}$, J-M A Lobaccaro ${ }^{1}$ and J R Drevet \\ Epididyme et Maturation des Gamètes, CNRS UMR 6547 GEEM, Université Blaise Pascal, 24, avenue des Landais, 63177 Aubière cedex, France \\ 1Physiologie Comparée et Endocrinologie Moléculaire, CNRS UMR 6547 GEEM, Université Blaise Pascal, 24, avenue des Landais, \\ 63177 Aubière cedex, France \\ 2Department of Pharmacology, University of Texas Southwestern Medical Center, Dallas, Texas 75390-9050, USA
}

(Requests for offprints should be addressed to J R Drevet; Email: joel.drevet@geem.univ-bpclermont.fr)

*(J-M Frenoux and P Vernet contributed equally to this work)

\begin{abstract}
In this study we looked at the epididymides and spermatozoa of mice knocked-out for nuclear oxysterol receptors (LXR). We have shown that LXR-deficient mice exhibited upon ageing a severe disruption of their caput epididymides associated with abnormal accumulation of neutral lipids. The epididymis defaults were correlated with sperm head fragility and infertility. In agreement with the observed caput defect in transgenic animals in which both LXR $\alpha$ and LXR $\beta$ isoforms were disrupted, we have shown here that both receptors are expressed in caput and cauda epididymides regions. LXR $\beta$ was predominantly expressed throughout the mouse epididymis while the expression of $\operatorname{LXR} \alpha$ was weaker. In addition, the expression of selected genes that can be considered as markers of adult epididymis function was monitored via Northern blots in the different single and double LXR-deficient backgrounds. Altogether, the data presented here suggest that LXR receptors are important actors in epididymis function.
\end{abstract}

Journal of Molecular Endocrinology (2004) 33, 361-375

\section{Introduction}

Cholesterol is an important actor in testicular and post-testicular maturational events that lead to the production of mature fertile spermatozoa. In the testis, male steroidogenic cells (i.e. Leydig cells) use cholesterol to actively synthesize steroids which are key factors in terms of male differentiation and germ cell production in the seminiferous tubules. Cholesterol is also important when it comes to post-testicular maturation of spermatozoa. A well-documented feature of epididymal maturation of spermatozoa is either their progressive loss of cholesterol while they transit through the organ or a decrease in the cholesterol/phospholipid molar ratio via the uptake of phospholipids into the sperm plasma membrane (Haidl \& Opper 1997). This results in changes in the sperm plasma membrane ability to fuse with the oocyte. Finally, cholesterol efflux has also been shown to be involved in signal transduction phenomena leading to sperm capacitation (for reviews see Cross 1998, Travis \& Kopf 2002).

Nuclear oxysterol receptors, or liver X receptors (LXRs), are members of the nuclear receptor superfamily that are bound to and activated by oxysterols, a specific class of oxidized derivatives of cholesterol. They bind DNA as obligate heterodimers with retinoid X receptors (RXRs), the receptor for 9-cis retinoic acid, onto cis-acting motifs of the DR4 type constituted of two direct repeats of an hexanucleotide motif (5'-AGGTCA-3') separated by four nucleotides (Repa et al. 2000). LXRs have been shown to regulate a wide variety of genes involved in the catabolism, transport and uptake of cholesterol and its metabolites, thereby controlling cholesterol elimination. Confirmation of this role came from the analysis of $l x r$-deficient mice 
Table 1 Oligonucleotide primers used in PCR assays

\begin{tabular}{|c|c|c|}
\hline & Nucleotide sequence $^{a}$ & $\begin{array}{l}\text { Length } \\
\text { (nucleotides) }\end{array}$ \\
\hline \multicolumn{3}{|l|}{$\begin{array}{l}\text { Primers } \\
\mathrm{LXR} \alpha\end{array}$} \\
\hline Forward & 5'-gatcggatccATGTCCTTGTGGCTGGAGG-3' & 29 \\
\hline Reverse & 5'-gatcctcgagTGGGAGGGTCTCTGCCTG-3' & 28 \\
\hline \multicolumn{3}{|c|}{$5 \sqrt{5-2}$} \\
\hline Forward & 5'-gatcggatccATGTCTTCCCCCACAAGTTC-3' & 30 \\
\hline Reverse & 5'-gatcctcgagTAAGATGACCACGATGTAGG-3' & 30 \\
\hline \multicolumn{3}{|c|}{ 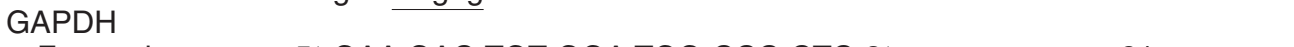 } \\
\hline Forward & 5'-GAA GAC TGT GGA TGG CCC CTC-3' & 21 \\
\hline Reverse & 5'-GTT GAG GGC AAT GCC AGC CCC-3' & 21 \\
\hline
\end{tabular}

(Peet et al. 1998a,b, Repa \& Mangelsdorf 2000, Venkatesvaran et al. 2000). Two isoforms, LXR $\alpha$ and LXR $\beta$, the tissue distribution of which differs, have been characterized. LXR $\alpha$ (NRIH3) expression in adult animals is predominant in tissues that are at the centre of lipid metabolism, including the liver, small intestine, spleen, adipose tissue, pituitary, adrenals and kidney, while LXR $\beta$ (NRIH2) was found to be ubiquitous (Repa et al. 2000).

The importance of cholesterol homeostasis in the maturation of spermatozoa leads to the tempting speculation that LXRs may play a specific role in these crucial processes. Interestingly, it was recently noticed that the fertility of mice in which both LXR receptors were disrupted dramatically decreased upon ageing (D H Volle, personal communication). Since male mice deficient for LXR $\alpha$ and LXR $\beta$ were fertile when younger (up to 6 months) we have assumed that their spermatogenic capacity was not primarily at stake. These observations prompted us to investigate more closely the impact of LXR disruption on the mouse epididymis. First, we investigated whether the LXR $\alpha$ and LXR $\beta$ receptors were expressed in wild-type (WT) adult epididymis. We then monitored the expression of genes that can be considered to be markers of the transcriptional activity of the different regions of the adult epididymis in the different single $\left(\mathrm{LXR} \alpha^{-/-}\right.$or LXR $\left.\beta^{-\prime^{-}}\right)$and double LXR (LXR $\left.\alpha \beta^{-\prime^{-}}\right)$ knockout backgrounds in order to see if the absence of LXR expression resulted in changes in epididymal gene expression. Finally, we carried out a histological analysis of the epididymides and spermatozoa of LXR $\alpha \beta$-null mice compared with WT mice.

\section{Materials and methods}

\section{Animals}

The generation of LXR-deficient mice has been described elsewhere (Peet et al. 1998a,b, Repa \& Mangelsdorf 2000, Venkatesvaran et al. 2000). Male mice of the BL6×129 Svj hybrid strain were reared in a temperature controlled $\left(22^{\circ} \mathrm{C}\right)$ atmosphere with a $12 \mathrm{~h}$ light: $12 \mathrm{~h}$ darkness cycle. Mice were handled according to the Guidelines on the Use of Living Animals in Scientific Investigations. Androgen supplementation was carried out with two daily subcutaneous injections ( $75 \mu \mathrm{g} /$ injection) of testosterone heptylate (Theramex Laboratories, Monaco) dissolved in sesame oil. Treatment was applied for 15 days to a pool of six animals. The control mice (six sham-operated animals) received equivalent injections of sesame oil only. Tissues were dissected as described earlier (Lefrançois et al. 1993), frozen in liquid nitrogen and stored at $-80^{\circ} \mathrm{C}$ before use. Unless otherwise indicated all chemicals were from Sigma-Aldrich (Saint Quentin Fallavier, France).

\section{PCR, RT-PCR and Northern blot hybridizations}

PCR amplifications and reverse transcription of total RNA were performed as described earlier (Drevet et al. 1994) using sets of specific primers (see Table 1) designed to amplify a $220 \mathrm{bp}$ long and a 
$180 \mathrm{bp}$ long LXR $\alpha$ and LXR $\beta$ cDNA fragment respectively. In order to carry out a semiquantitative evaluation of the epididymal expression of LXR receptors, amplification of an internal standard (glyceraldehyde-3-phosphate dehydrogenase (GAPDH), see Table 1) was performed in the same reactions. For the extraction of total RNA, liver and epididymides were processed as previously reported (Ghyselinck et al. 1993). Northern blot analyses were carried out using formaldehyde agarose (1.5\%; w/v) gels essentially as described (Sambrook et al. 1989). Randomprimed labelled (MegaprimeTM; Amersham, Les Ulis, France) cDNA fragments corresponding to the complete open reading frame of the glutathione peroxidase GPX3, GPX5 and the Ets-like polyoma enhancer activator 3 trans-acting factor (PEA3) mRNAs were used as probes (Vernet et al. 1996, Drevet et al. 1998, Schwaab et al. 1998). Homogeneity in RNA loading was monitored by a subsequent hybridization of each blot with an $18 \mathrm{~S}$ ribosomal RNA random-labelled cDNA probe.

\section{SDS-PAGE and Western blot analyses}

Tissues were treated as described earlier (Vernet et al. 1997). Protein electrophoresis was performed as originally reported by Jimenez et al. (1990) with the modifications described by Vernet et al. (1997). Western blot analyses were carried out using the ECLTM detection system (Amersham). Blots were incubated at room temperature with the primary antibody for $4 \mathrm{~h}$ (dilution 1/3000). The antibody against maize (m)LXR $\alpha$ (Volle et al. 2004) recognizes the $\mathrm{N}$-terminal domain of the $\mathrm{LXR} \alpha$ receptor. An anti-rabbit IgG labelled with horseradish peroxidase was used as secondary antibody (dilution 1/10 000). Blots were then exposed for $2 \mathrm{~min}$ at room temperature against autoradiographic films (Kodak; X-Omat AR/5).

\section{Histological analyses}

Following anaesthesia and death by cervical dislocation, organs were rapidly dissected and fixed by immersion in ethanol/acetic acid buffer (3/1; v/v) for $30 \mathrm{~min}$. Organs were then dehydrated using $100 \%$ ethanol followed by butanol washes and embedded in paraffin (Faure et al. 1991). Blocks were sectioned at $5 \mu \mathrm{m}$ and sections were deparaffinized (Histoclear) and rehydrated through washing in se- rial dilutions of alcohol into water. Sections were stained for $3 \mathrm{~min}$ with Masson's Hemalun solution $(0 \cdot 2 \%(\mathrm{w} / \mathrm{v})$ haematein, $5 \%(\mathrm{w} / \mathrm{v})$ aluminium potassium, 2\% (v/v) acetic acid; Sigma-Aldrich), then washed for $3 \mathrm{~min}$ under tap water. Sections were then stained with $0 \cdot 3 \%(\mathrm{w} / \mathrm{v})$ carmin indigo in saturated picric acid for $30 \mathrm{~s}$. Excess carmin indigo stain was washed out in a bath of absolute ethanol. Alternatively, sections were in some cases stained for $5 \mathrm{~min}$ in a solution of Giemsa (Sigma) diluted into water $(1 / 20)$. For red oil staining of lipids, cryosections were used. Tissue samples were immersed in OCT (Miles Scientific, Naperville, IL, USA) and immediately frozen in liquid nitrogen. Sections $(10 \mu \mathrm{m})$ were cut using a S030 microtome cryostat (Bright Instrument Co. Ltd, Huntingdon, Cambs, UK). For the detection of neutral lipids, red-oil O staining was used as originally described by Lillie \& Ashburn (1943).

\section{Sperm retrieval from cauda epididymides}

Cauda epididymides were minced either in classical $1 \times$ phosphate-buffered saline $(\mathrm{KCl} \quad 2 \cdot 7 \mathrm{mM}$, $\mathrm{KH}_{2} \mathrm{PO}_{4} \quad 1.5 \mathrm{mM}$, NaCl $137 \mathrm{mM}, \quad$ pH $\quad 7 \cdot 2$, $\mathrm{Na}_{2} \mathrm{HPO}_{4} 8.1 \mathrm{mM}$ and EDTA $1 \mathrm{mM}$ ) or in Whittingham's medium (NaCl $100 \mathrm{mM}, \mathrm{pH} 7 \cdot 2$, $\mathrm{Na}_{2} \mathrm{HPO}_{4} \quad 16 \mathrm{mM}, \quad \mathrm{CaCl}_{2} \quad 1.8 \mathrm{mM}, \quad \mathrm{MgCl}_{2}$ $0.5 \mathrm{mM}, \quad \mathrm{Na}_{2} \mathrm{CO}_{3} 20 \mathrm{mM}$, glucose $5.5 \mathrm{mM}$, sodium pyruvate $0.5 \mathrm{mM}$, sodium lactate $18.7 \mathrm{mM}$ ). Minced tissues were then gently agitated to allow sperm dispersion. Epididymal tissues were removed after centrifugation for $5 \mathrm{~min}$ at $100 \mathrm{~g}$. Spermatozoa were concentrated by centrifugation for $5 \mathrm{~min}$ at $500 \mathrm{~g}$.

\section{Results}

\section{LXR receptors are differentially expressed in the mouse epididymis}

We used RT-PCR to show that LXR receptors are expressed in the mouse adult epididymis. Figure 1A presents a typical amplification showing that both LXR $\alpha$ and LXR $\beta$ mRNAs are present in total RNA samples prepared from caput and cauda epididymides of adult WT male mice (9 months of age). To evaluate, in a semi-quantitative manner, the level of expression of LXR $\alpha$ and LXR $\beta$ receptors in the epididymis territories, GAPDH amplification was carried out in the same reactions 


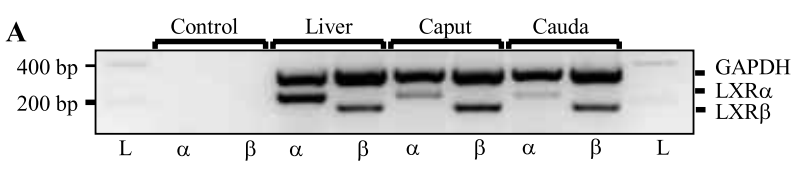

B

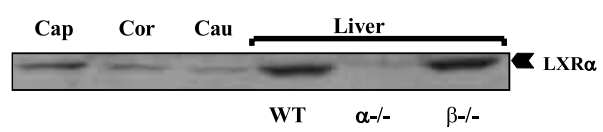

Figure $1 \mathrm{LXR} \alpha$ and $\mathrm{LXR} \beta$ detection in the mouse epididymidis. (A) PCR amplifications of $L X R \alpha$ and $L X R \beta$ cDNAs in reverse-transcribed total RNA prepared from caput or cauda epididymides as well as liver tissue samples. Numbers in the right margin indicate the size (in bp) of the expected amplified fragment (220 bp for $L X R \alpha, 180$ bp for $L X R \beta$ and 358 bp for the GAPDH standard respectively). Numbers indicated on the left indicate the position and size of selected bands of the DNA ladder (SmartLadder; Eurogentec, Serain,

Belgium) run in lane $L$. (B) Immunodetection of $L X R \alpha$ in caput epididymis protein samples. Total protein samples from caput (Cap), corpus (Cor), cauda (Cau) epididymides and liver of WT mice were treated with a purified polyclonal serum directed against a bacterially expressed recombinant LXR $\alpha$ protein (Volle et al. 2004). The arrowhead on the right indicates the position of the $\mathrm{LXR} \alpha$ protein.

and, in addition, control amplifications were performed using reverse-transcribed total liver RNA from the same mice. This showed that the LXR $\beta$ receptor was expressed throughout the epididymis at a level comparable to that of the liver while the $\mathrm{LXR} \alpha$ receptor appeared to be less represented in the epididymis than in the liver, and also slightly less represented in the cauda than in the caput epididymidis.

Using a purified polyclonal antibody generated in house for the mouse LXR $\alpha$ protein (Volle et al. 2004), we carried out a western blot analysis of mouse epididymis protein extracts. The Western blot analysis presented in Fig. $1 \mathrm{~B}$ shows that the $\mathrm{LXR} \alpha$ protein was indeed present in caput epididymis protein extracts. In agreement with the semi-quantitative RT-PGR approach reported above, the western analysis revealed that the LXR $\alpha$ receptor was less abundant in epididymis than in liver and, within the epididymis itself, more abundant in caput protein extracts when compared with corpus and cauda samples. As positive controls, total protein extracts prepared from the liver of the same animals as well as from LXR $\beta^{-/-}$knockout animals were provided while, as negative controls, total protein extracts of $\mathrm{LXR}^{-/-}$knockout mice are shown.

\section{Expression of epididymal genes is affected in LXR knockout mice}

Northern experiments were carried out in order to see if the disruption of LXR receptors induced any change in epididymal gene expression. Total RNAs were prepared from the epididymides of LXR knockout mice and hybridized with probes for genes that can be considered as markers of epididymal function. Specific cDNA probes were synthesized for the caput-restricted genes encoding GPX5 (Vernet et al. 1997) and PEA3 (Lan et al. 1997, 1998, 1999, Drevet et al. 1998). In parallel, the gene coding for the plasma-type GPX3, known to be expressed at a significant level in the mouse cauda epididymis (Schwaab et al. 1998), was also used as a probe. RNA samples were prepared from 11-month-old animals and RNA loadings were normalized using an $18 \mathrm{~S}$ ribosomal RNA probe. A typical northern blot is shown in Fig. 2A while densitometric analyses of northern blots from three different experiments using pools of epididymides from distinct knockout animals are shown in Fig. 2B. The analysis revealed that changes in epididymal gene expression were obvious for mice in which both LXR $\alpha$ and LXR $\beta$ were disrupted. Variations in gene expression particularly concerned the caput region of the epididymis. Indeed, in the caput of LXR $\alpha \beta$-null mice we recorded a strong decrease in the accumulation of both the caput-restricted GPX5 and PEA3 mRNAs (Fig. 2B). In agreement with the higher expression of LXR $\beta$ versus LXR $\alpha$ throughout the epididymis, the decrease in the accumulation of GPX 5 and PEA3 mRNAs was less pronounced in the single LXR $\alpha$ knockout animals than in $\operatorname{LXR} \beta^{-{ }^{-}}$or in $\operatorname{LXR} \alpha \beta^{-/-}$animals. This was also true for the accumulation of the PEA3 mRNA which, in LXR $\beta^{-1-}$ animals, appeared at a level comparable to that recorded in the double LXR mutant animals $\left(\operatorname{LXR} \alpha \beta^{-/-}\right)$. It was also true for the cauda-expressed GPX3 gene transcript accumulation, which was significantly reduced in the LXR $\beta^{-\prime-}$ animals while it did not change significantly in either the $\operatorname{LXR} \alpha^{-/-}$or the $\operatorname{LXR} \alpha \beta^{-/-}$ animals.

\section{Are caput-expressed genes targets for LXRs?}

To determine whether caput-expressed genes (such as GPX5 or PEA3) could be direct LXRs target genes, we first carried out a computer-assisted 

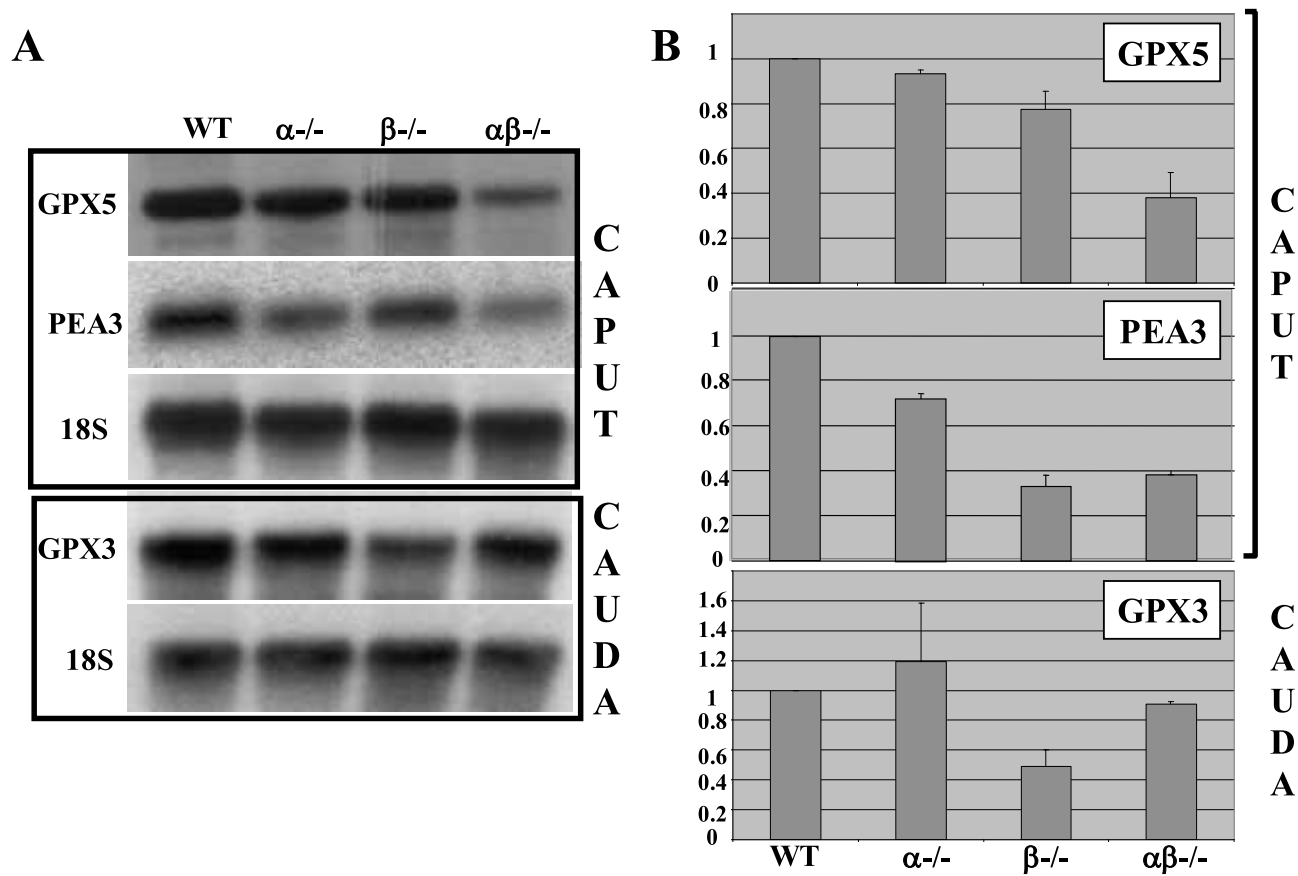

Figure 2 Expression of selected epididymal genes in the LXR $\alpha$ and/or LXR $\beta$ knockout animals. (A) A typical Northern blot experiment of caput and cauda total RNA from WT, LXR $\alpha$-deficient $(\alpha-/-)$, LXR $\beta$-deficient ( $\beta-/-)$ and LXR $\alpha \beta$-deficient $(\alpha \beta-/-)$ mice hybridized with radiolabelled cDNA probes for the caput-specific GPX5 and PEA3 transcripts as well as for the cauda epididymis-expressed plasma-type GPX3 transcript. For the purpose of quantification, each blot was stripped and hybridized with a radiolabelled cDNA probe for the $18 \mathrm{~S}$ ribosomal RNA. (B) Densitometric analyses of three distinct Northern blot experiments (as in A).

search to screen for the presence of consensual LXR response elements (LXRE) of the type 5'DGGTYAyynnVGKKCA-3' within their regulatory gene sequences (Volle et al. 2004). One highly degenerate putative LXR-binding site was found in the distal GPX5 5'-flanking promoter region (Fig. 3A). In order to see whether the GPX5 gene could be regulated by LXRs, we fed WT mice with an agonist of LXR (T0901317=T1317) (Sigma) and monitored the accumulation of the GPX 5 mRNA. No significant variation in the epididymal accumulation of the GPX5 mRNA was detected (Fig. 3B) in T1317-fed animals after $12 \mathrm{~h}$, suggesting that $g p \times 5$ is not directly regulated by LXRs. A PEA 3 probe was also tested on the same blot and, as was the case for GPX5, no variation in the accumulation of the PEA3 transcript was detected (not shown). Because of the presence of a blood/epididymis barrier that could eventually protect the epididymal territory from the systemic action of the LXR agonist, we investigated the behaviour of a known LXR target gene, abco (Venkatesvaran et al. 2000) within the epididymides of T1317-fed animals. Since the level of expression of $a b c 8$ within the mouse epididymis is low, a semi-quantitative RT-PCR approach was carried out to evaluate the epididymal effect of the LXR agonist. A typical amplification presented in Fig. 3C shows that T1317 administration is followed by an increase in the accumulation of the $a b c 8$ transcript in WT mouse epididymis. In addition, Fig. 3C shows that T1317 treatment of caput epididymal culture cells (Britan et al. 2004) is followed by an increase in the accumulation of $a b c 8 \mathrm{mRNA}$ recorded after 12, 24 or $48 \mathrm{~h}$, confirming that, in vitro as in vivo epididymal epithelial cells can respond to the LXR agonist.

\section{Histological analysis of the epididymides in LXR $\alpha \beta^{-I-}$ animals}

The decrease in the caput accumulation of the GPX5 and PEA3 mRNAs associated with the 
A

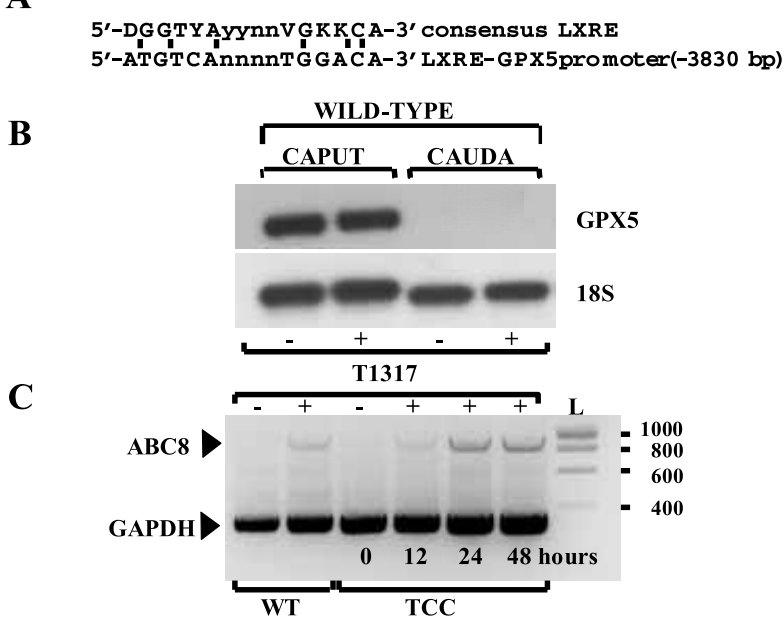

Figure 3 GPX5 is not a target gene for LXR.

(A) Sequence alignment of the unique LXRE found in silico within the distal $5^{\prime}$-flanking sequence of the mouse GPX5 gene with a cannonical LXRE. (B) Typical Northern blot in which caput and cauda total RNA from normal (-) or T1317-injected (+) WT mice hybridized against the caput-specific GPX5 cDNA probe and standardized with the 18S ribosomal RNA cDNA probe.

(C) PCR amplifications of the abc8 transcript (ABC8), a known target gene of LXRs, in caput epididymal reverse-transcribed total RNA from WT, normal (-), T1317-gavaged (+) animals or mouse caput epithelial tissue culture cells (TCC) treated for 12,24 or $48 \mathrm{~h}$ with T1317. Control cells not treated with the LXR agonist are presented lane 0 . Numbers indicated on the right give the position and size of bands of the DNA ladder (SmartLadder) run in Lane L.

observation that the caput-expressed genes $g p x 5$ and PEA3 were unlikely to be directly regulated by LXRs prompted us to look more closely at the epididymis epithelium of LXR mutant animals. No difference was observed in the histology of the epididymis of LXR $\alpha$ or LXR $\beta$ single knockout mice compared with the WT (not shown). On the contrary, a dramatic disruption of the caput epididymal histology was detected in animals (aged 10 months) in which both $l x r \alpha$ and $l x r \beta$ were invalidated (Fig. 4). Gross macroscopical observations of the epididymides upon dissection did not reveal drastic variations although caput epididymides were found to be slightly enlarged and spongy when compared with controls. No strong difference was observed in the amount of fat pad associated with the caput. A typical caput section of $\operatorname{LXR} \alpha \beta^{-/-}$mice is shown in Fig. 4A (right panel). Overall, we detected no difference in the regionalization of the caput epidi- dymides, since the various segments reflecting the spatial organization of the caput (segments 1 to 5 in the antero-posterior axis as defined by Abou-Haila \& Fain-Maurel 1984) were there and correct in size and organization. However, a strong disruption of the caput epithelium especially in the proximal region, the so-called segments 1 and 2 (initial segment and proximal segments), was observed. When compared with a typical control caput (Fig. 4A, left panel), the differences were in the size and thickness of the epithelium of the epididymal tubules. In addition, and in agreement with the spongier aspect of the organ, some tubule sections lacked any luminal content while other tubule sections were filled up with amorphous substances. At higher magnification (Fig. 4B), we observed that the major difference detected in the caput segment 2 area of LXR $\alpha \beta^{-/-}$animals was in the thickness of the epithelium (compare left and right panels in Fig. 4B). Epithelial principal cells were there as reflected by the presence of nuclei, but they no longer appeared as high columnar epithelial cells. The apical membrane was in close proximity to the nuclei, and stereocilia which are characteristic of the principal cells of this region of the organ (especially in segment 2) were absent.

\section{Temporal evaluation of the setting up of the caput segment 2 defect in the LXR $\alpha \beta^{-/-}$animals}

In order to investigate the appearance of the epididymis defect in the double LXR knockout mutants we analyzed the histology of caput segment 2 in LXR $\alpha \beta$ knockout animals at various ages. Caput sections presented in Fig. 5 show that from 2 to 5 months of age the histology of caput segment 2 tubules is not disturbed when compared with control animals (inserts). At 5.5 months of age, we detected a slight decrease in the thickness of the tubule epithelium and by 6 months the principal cells of caput epididymal segment 2 epithelium were as fully disturbed as they appeared in mice of 10 months of age (see Fig. 4B). Sections shown are typical sections from at least three animals at each age.

\section{Histological evaluation of the luminal content of caput segment 2 and cauda sections in LXR $\alpha \beta^{-/-}$animals}

Sections of LXR $\alpha \beta^{-/-}$caput segment 2 presented in Fig. 6 show some examples of the 


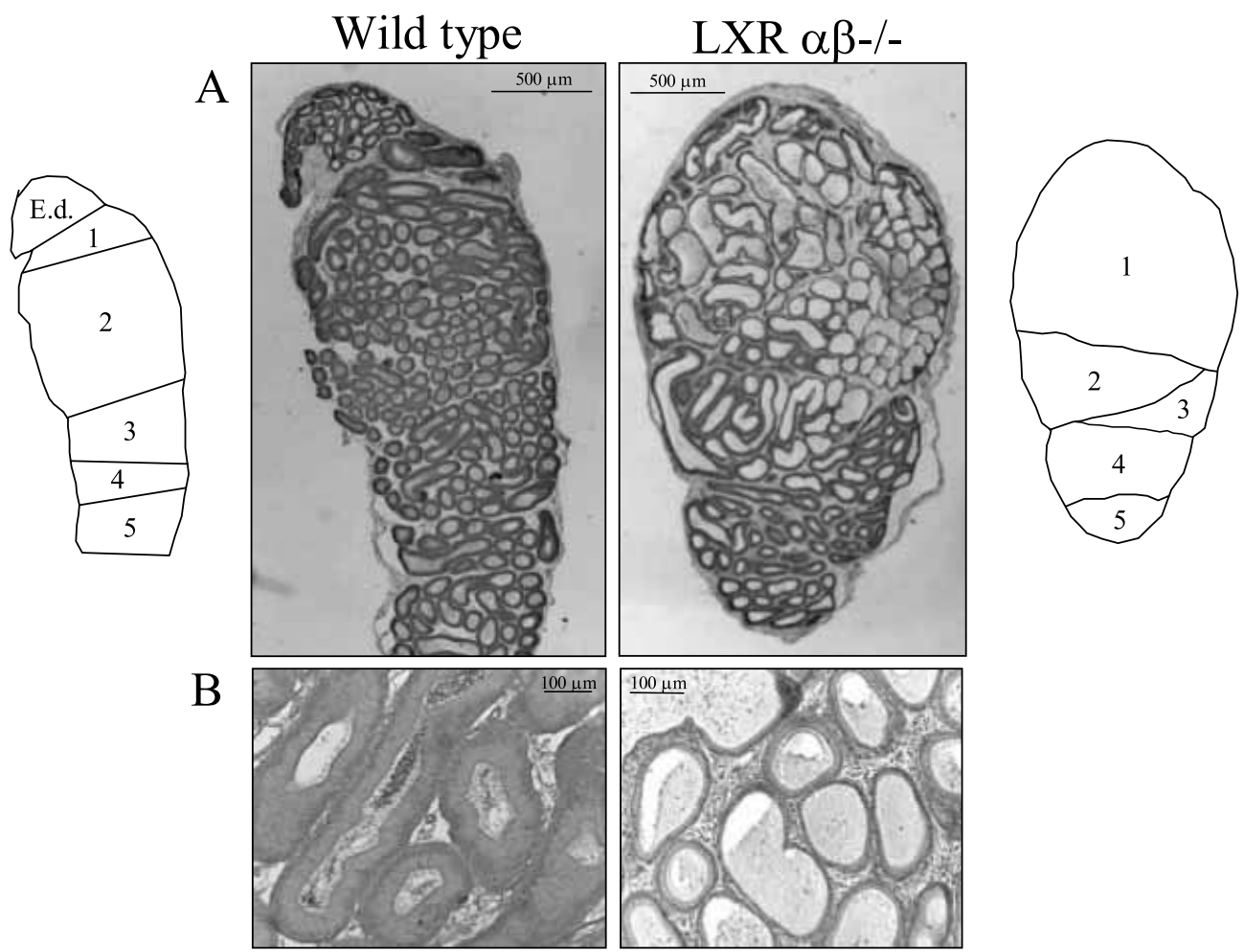

Figure 4 Histological analysis of the epididymides of LXR-deficient animals. (A) Histological sections of caput epididymides from WT (left side) and LXR $\alpha \beta$-deficient animals (right side). Drawings in the left and right margins indicate the various subterritories (segments 1 to 5 of the caput) as defined by Abou-Haïla \& Fain Maurel (1984). E.d.=efferent ducts. (B) Higher magnification of caput segment 2 sections showing the drastic difference in the thickness of the epithelium in WT animals (left) versus LXR $\alpha \beta$-null mice (right side).

heterogeneity that we have observed in the luminal content of epididymal tubules. WT caput segment 2 tubule sections (Fig. 6A) are presented with their classical appearance being that of a tall epithelium with numerous luminal spermatozoa as revealed by the presence of dark condensed nuclei and flagella. In LXR $\alpha \beta^{-/-}$animals, some caput segment 2 tubules were nearly empty while other tubules in the same area either contained vesicular-type structures or/and were filled with an amorphous substance with very few visible spermatozoa (Fig. 6B). In some sections (Fig. 6C), cellular-like/vesicular-like structures were found within the luminal compartment. Finally, vesicular structures were also found to be abundant in the epithelium of the tubule sections (see Fig. 6D and see also Fig. 8A) as well as in the underlying connective tissues (Fig. 8A).

To address the question as to whether or not the amorphous substance that is accumulated in the lumen of some of the caput segment 2 sections as well as the vesicular inclusions detected in the tubule epithelium could be of lipidic nature, we subjected cryosections to oil-red $\mathrm{O}$ staining. Oil red specifically stains neutral lipids such as triglycerides and cholesterol. Figure $7 \mathrm{~B}$ and $\mathrm{G}$ shows that the luminal compartment of caput segment 2 tubules from LXR $\alpha \beta^{-1-}$ animals (6 months old) did not show any strong reactivity, suggesting that the luminal-accumulated materials are not prominently constituted of lipids. On the contrary, it was clear that both the epithelium and the interstitium of caput segment 2 sections from $\operatorname{LXR} \alpha \beta^{-/-}$ animals were highly reactive towards oil-red $\mathrm{O}$, suggesting that accumulation of neutral lipids occurred in LXR-deficient animals (compare Fig. 7A with B and C). A control section of WT caput epididymis (segment 2) at the same age, where no staining is detected, is provided in Fig. 7A. At a more advanced age (12 months) the caput segment 2 epithelium contained numerous 

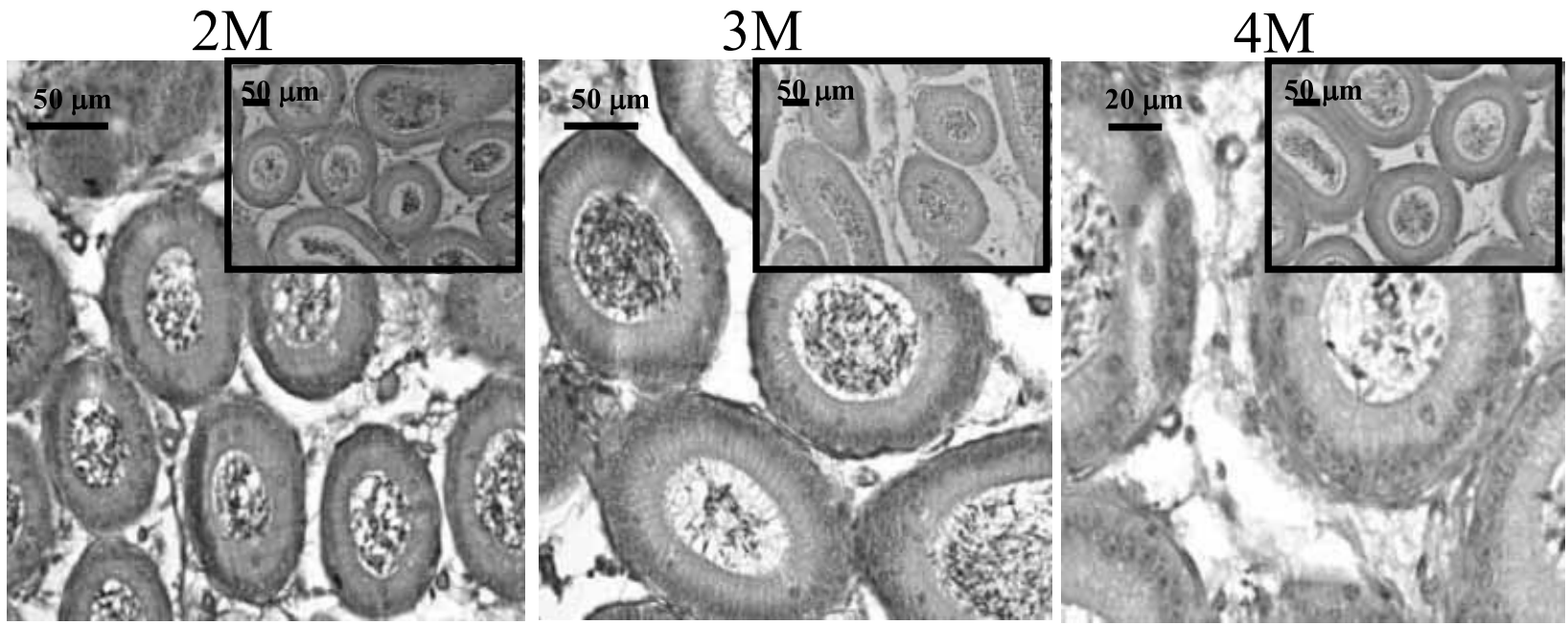

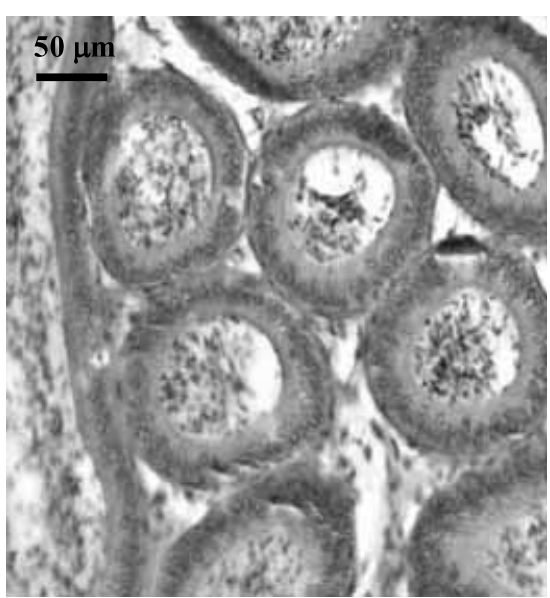

$5 \mathrm{M}$

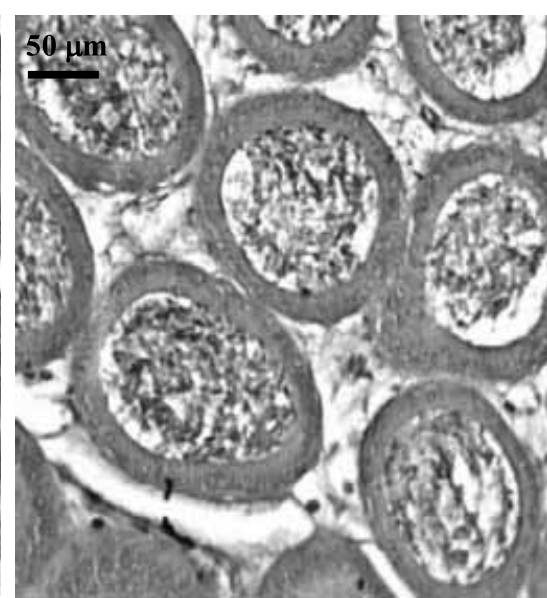

$5.5 \mathrm{M}$

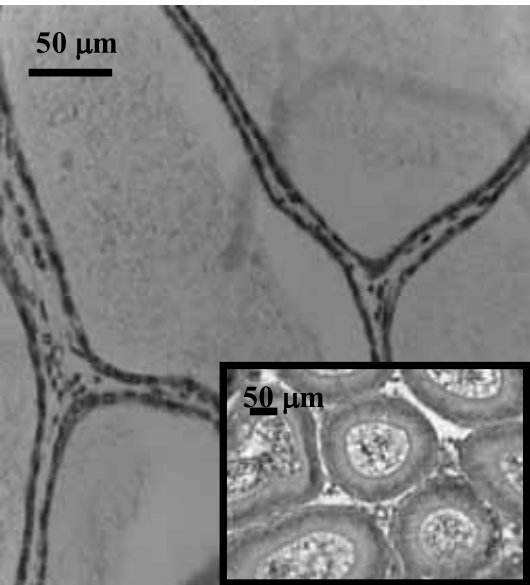

$6 \mathrm{M}$

Figure 5 The epididymal defect of LXR $\alpha \beta$-deficient mice occurs around 6 months of age. Caput segment 2 sections of LXR $\alpha \beta$-null mice at 2, 3, 4, 5, 5.5 and 6 months of age (M). Inserts within panels (2, 3, 4 and 6 months old) show a photograph of a control caput segment 2 section of a WT animal at the same age.

vesicles (Fig. 8A) which were highly reactive toward oil-red O (Fig. 8B).

In order to assess if spermatozoa were affected in the LXR $\alpha \beta^{-1-}$ background we prepared sperm samples from cauda epididymides of 11-month-old LXR $\alpha \beta^{-\prime^{-}}$and WT mice (Fig. 9). Spermatozoa from the double $\operatorname{LXR} \alpha$ and $\beta$ transgenic animals were scarce and structurally abnormal. They exhibited a structural fragility since, in spermatozoa preparations from LXR $\alpha \beta^{-/-}$cauda epididymides, sperm heads were systematically separated from their flagella (Fig. 9A). Moreover, flagella were abnormal and presented various degrees of angulation, being either bent at various angles or in a hairpin structure.

\section{Androgens cannot restore the epididymal defect of LXR $\alpha \beta^{-/-}$animals}

Since the maintenance of the differentiated state of the epididymis epithelium is largely under the dependence of androgens, an evaluation of the concentration of circulating androgens in LXR $\alpha \beta^{-/-}$transgenic animals was carried out. Androgen concentrations were found to be reduced in 5-month-old animals null for LXR $\alpha$ and LXR $\beta$, suggesting that testis functions were also disturbed in LXR-deficient mice (D H Volle, unpublished observations). In order to evaluate whether the epididymal defect was correlated with the decrease in circulating androgens, we supplemented $7 \cdot 5$ - and 


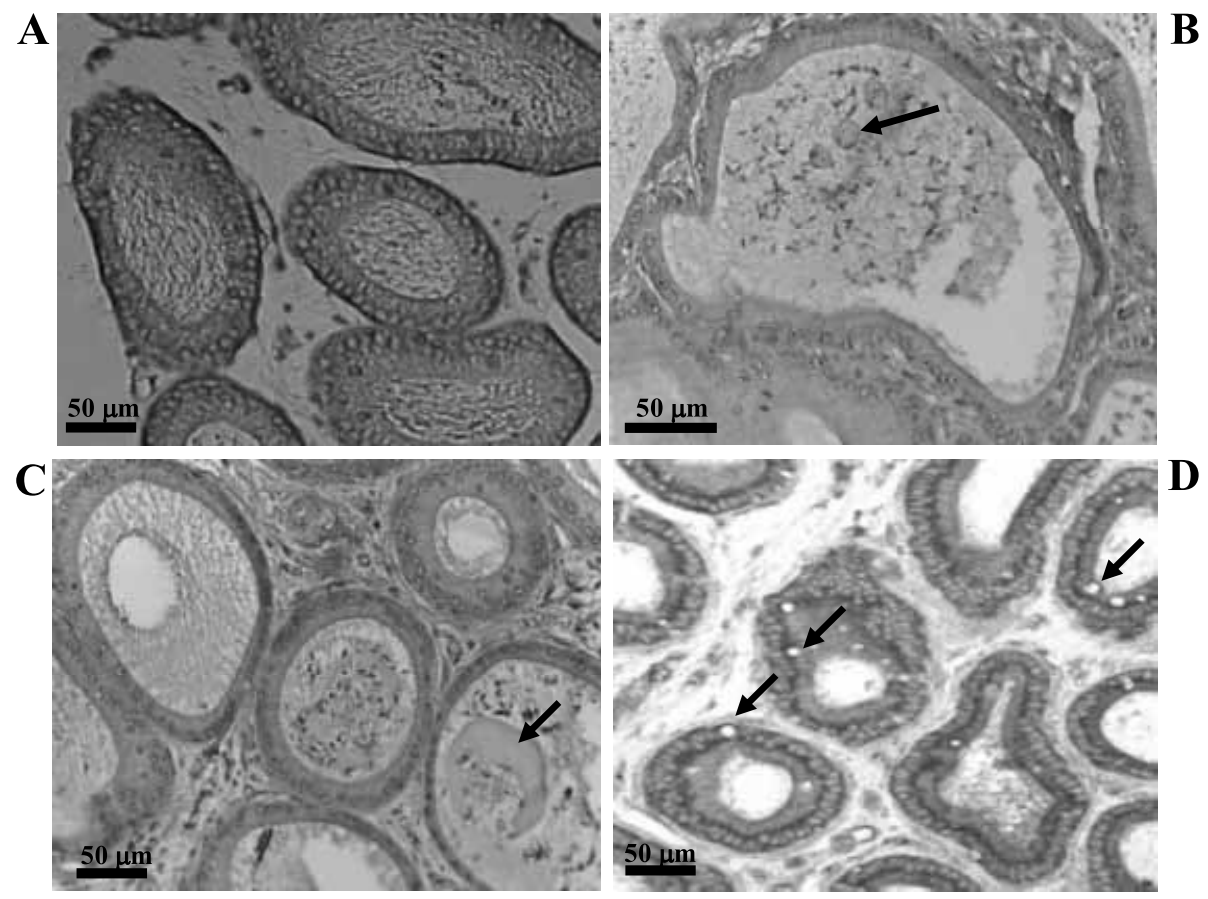

Figure 6 Peculiar caput epididymal luminal contents and epithelial structures in LXR $\alpha \beta$-deficient mice. (A) Caput segment 2 sections of WT control mice. Note that the lumen of each section is filled with spermatozoa. (B) Caput segment 2 sections of LXR $\alpha \beta$-deficient mice over 6 months of age showing the heterogeneity in the tubule appearance and the presence of unusual cell-like structures (arrow).

(C) Typical sections of the caput segment 2 region from $L X R \alpha \beta$-null mice showing the presence of vesicular-like structure in the lumen of the tubules (arrow) as well as what looks like empty droplets in the epithelium lining the tubules (see arrows in (D)). (D) Note that lumens are empty in some areas of caput segment 2 from LXR $\alpha \beta$-null mice.

10.5-month-old LXR $\alpha \beta^{-/-}$mice with testosterone for 15 days and carried out an histological analysis of their caput epididymides. The addition of androgens did not correct the abnormal caput epithelium of LXR-deficient mice (not illustrated). These data suggested that androgens alone are not solely responsible for the specific phenotype observed in the proximal segments of the caput epididymides in LXR $\alpha \beta^{-/-}$animals.

\section{Discussion}

Since lipid homeostasis is crucial for the acquisition of sperm fertilizing ability, we raised the question of the role of LXRs in the epididymis. Our data have shown that both $\alpha$ and $\beta$ isoforms of the LXRs are expressed in the normal adult mouse epididymis. In addition, although only semi-quantitative RT-PGR was used, our results indicated, at least for $\operatorname{LXR} \alpha$, that it is preferentially expressed in the mouse caput versus the cauda epididymides. The availability of an in-house-generated polyclonal serum directed against the mouse LXR $\alpha$ isoform allowed us to show that the LXR $\alpha$ protein is indeed present at detectable levels in caput epididymal protein samples. In agreement with the suggested caput higher accumulation of the $\operatorname{LXR} \alpha$ transcript, the LXR $\alpha$ protein was found to be less abundant in corpus and cauda epididymal protein samples.

Northern experiments using total RNA samples from epididymides of transgenic animals in which both LXR $\alpha$ and LXR $\beta$ were disrupted showed a strong decrease in the accumulation of transcripts for caput epididymidis restricted genes (namely GPX5 and PEA3). In contrast, mRNA accumulation of a cauda preferentially expressed gene (GPX3) was not drastically changed in the same 


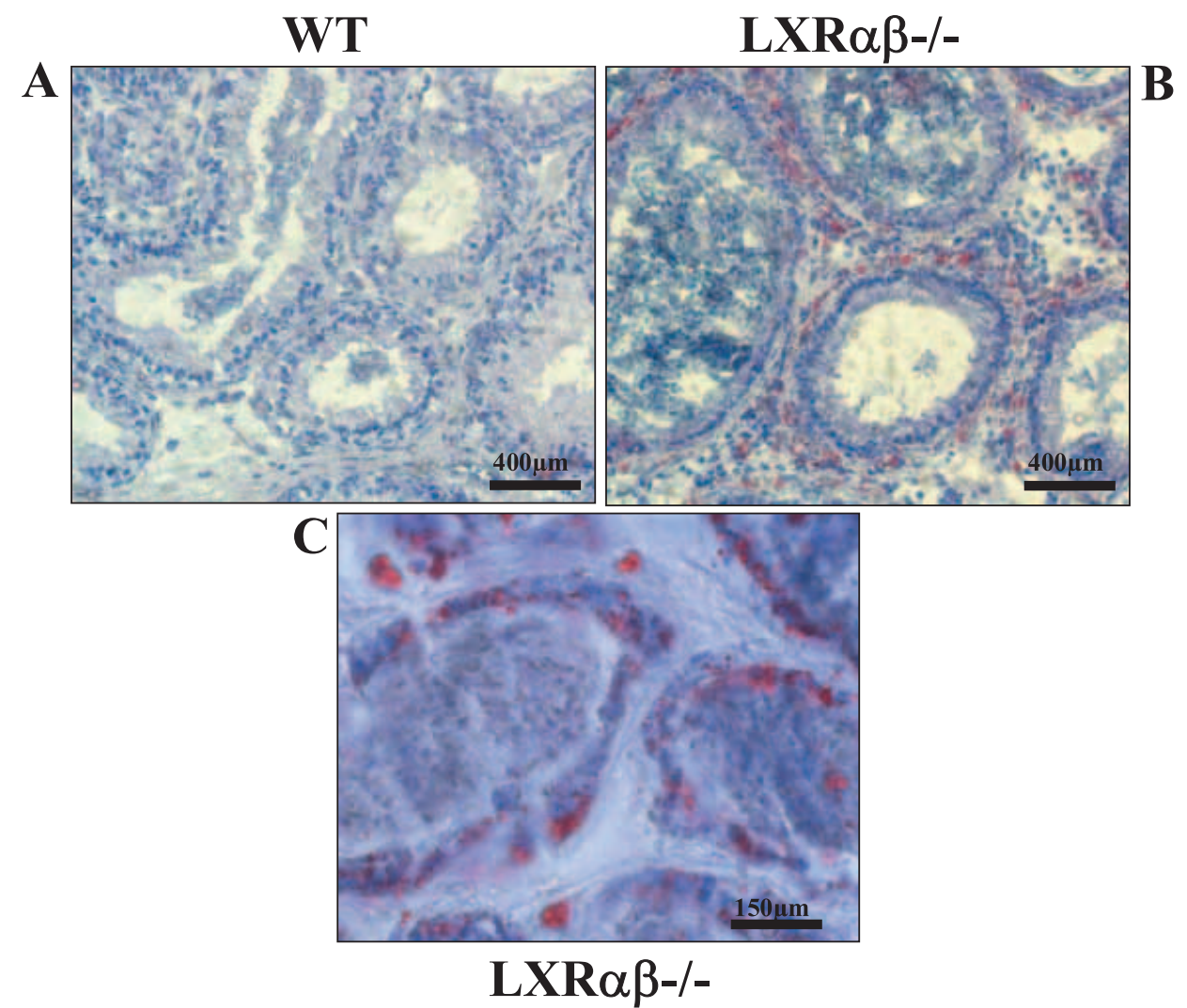

Figure 7 Oil-red $\mathrm{O}$ staining of caput segment 2 sections. (A) Control section of 6-month-old WT animal stained with oil-red O. (B) Identical section of a 6-month-old $\mathrm{LXR} \alpha \beta^{-1-}$ animal stained with oil-red $\mathrm{O}$ showing that the amorphous substance found in the tubule luminal compartments is not primarily of lipidic nature and that lipids accumulate significantly within the epithelium and in the interstitium. (C) Higher magnification of a caput segment 2 tubule of an LXR $\alpha \beta$-deficient animal stained with oil-red O.

animals while on the contrary GPX3 expression seems to be significantly affected in the single LXR $\beta^{-\prime-}$ animals. Altogether, these data indicated that the mouse epididymis is somehow under the control of LXR receptors. In the single LXR $\alpha$ or LXR $\beta$ knockout models the decrease we recorded in the accumulation of caput GPX5 and PEA3 transcripts was not as pronounced as in the double knockout mice, suggesting that $\operatorname{LXR} \alpha$ and LXR $\beta$ can partially, but not totally, compensate for each other. This could suggest that LXR $\alpha$ and LXR $\beta$ do not play totally the same roles and are likely to have distinct target genes in the mouse epididymis. The down-regulation of GPX3 expression in cauda epididymis in $\operatorname{LXR} \beta^{-/-}$animals associated with the absence of effect on GPX3 mRNA accumulation when LXR $\alpha$ is disrupted support this hypothesis. This is in good agreement with the literature since, in contrast to $\operatorname{LXR} \alpha$, the function of LXR $\beta$ is not clear (Peet et al. 1998a,b). It was shown that, although LXR $\beta$ is expressed in the liver and seems to respond to the same ligands as $\operatorname{LXR} \alpha, \operatorname{LXR} \beta$ is unable to rescue the phenotype of the LXR $\alpha^{-/-}$mice clearly (Peet et al. 1998a,b). In addition, despite broad tissue distribution and early embryonic expression of LXR $\beta$, mice null for LXR $\beta$ did not show any obvious phenotype (Peet et al. 1998a,b). In our case too, disruption of LXR $\beta$ was not associated with an obvious phenotype in the epididymis. These observations led Peet et al. to the conclusion that, at least in liver, $\operatorname{LXR} \alpha$ and LXR $\beta$ might have distinct target genes and are likely to have different functions. Only recently, skin defects have been reported for $\operatorname{LXR} \beta^{-/-}$ 


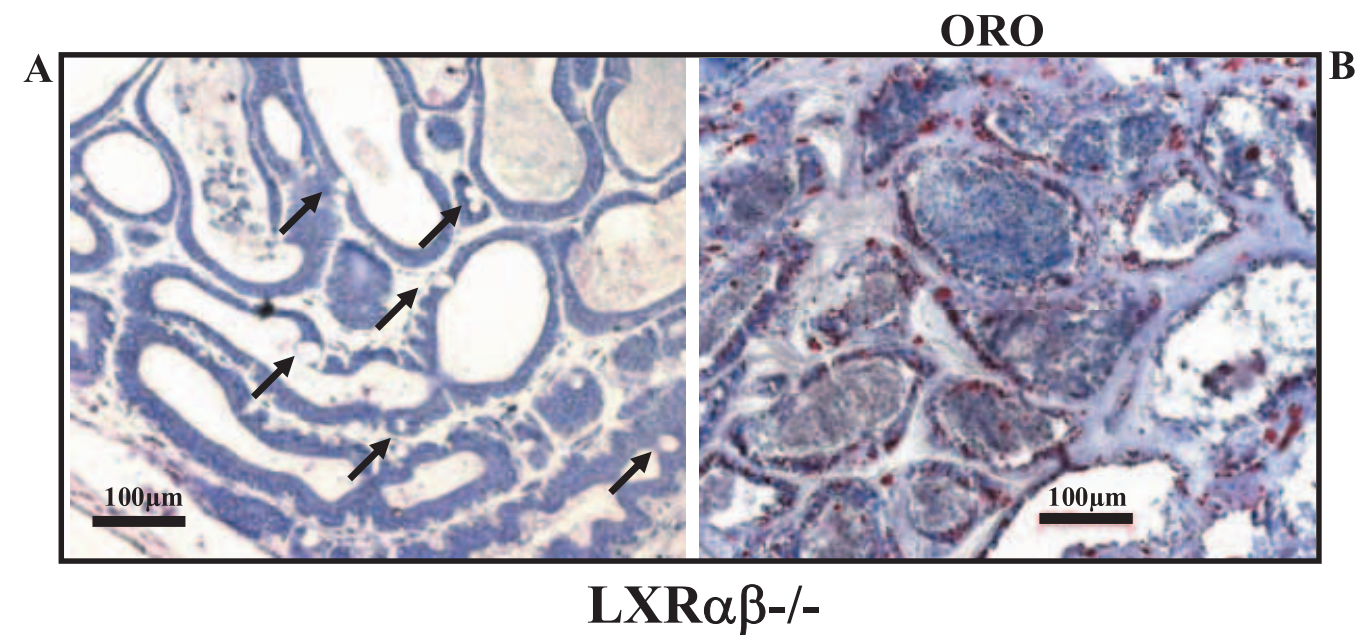

Figure 8 Typical cryosection of LXR $\alpha \beta$-deficient mouse caput (segment 2) aged 11 months showing $(A)$ the highly disrupted epithelia and the presence of vesicular structures (arrows). In (B) an identical section stained with oil-red O (ORO) shows the strong accumulation and the co-localization of lipid droplets around the vesicular structures in the defective epithelium.

animals (Komuves et al. 2002), suggesting that LXR $\beta$ might play some specific roles in epithelia. Our observation that epididymal genes seem to be more affected by the disruption of $\operatorname{LXR} \beta$ than LXR $\alpha$ most likely simply reflects the higher epididymal expression of LXR $\beta$ than of LXR $\alpha$. In any case, it renders the epididymis an attractive tissue to screen for specific LXR $\beta$ target genes in the reproductive tract. Among epididymal genes, our investigations suggest that $g p \times 5$ and pea3 are not direct target genes for LXRs since these genes were not up-regulated in WT animals fed an agonist of

\section{$\mathbf{L X R} \alpha \beta-/-$}

A

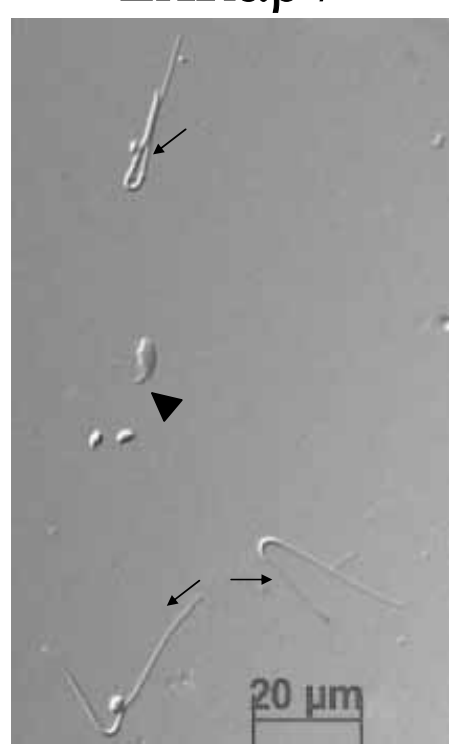

WT

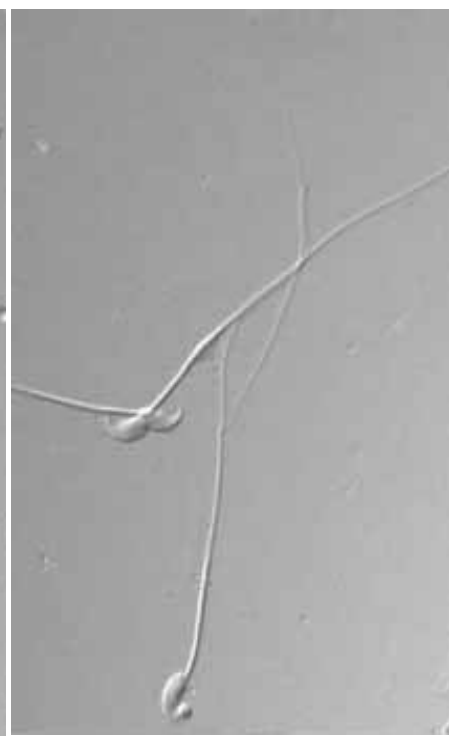

B

Figure 9 Morphology of spermatozoa in LXR $\alpha \beta$-null mice versus WT mice. Spermatozoa were collected from the cauda epididymal lumen of WT mouse and LXR $\alpha \beta$-deficient mice (11 months of age). Arrows indicate either bent or hairpin flagella while the arrowhead points out an isolated sperm head. 
LXR (T1317). The assumption that gpx5 could be regulated by LXRs is not too farfetched, because it was shown that some GPXs can use oxidized forms of cholesterol as substrates (Hurst et al. 2001). It was therefore expected that LXRs functioning as oxysterol sensors would also directly regulate genes involved in oxysterol catabolism. Knowing that a blood/epididymis barrier exists, we thought that it might protect the epididymis cells from the effect of the LXR agonist. However, we have shown here that $a b c 8$, a known target gene of LXR (Venkatesvaran et al. 2000), is up-regulated in WT mice fed with T1317, suggesting that the drug was able to reach the tissue despite the presence of the epididymis/blood barrier. In addition, akr1b7, another reported target gene of LXRs (Volle et al. 2004), was shown to be up-regulated by the LXR agonist in the testes of the same animals ( $\mathrm{D} \mathrm{H}$ Volle, unpublished observations). These data revealed that the T1317 drug was able to cross the testicular/blood barrier, which is known to be tighter than the epididymis/blood barrier. Thus, the absence of effect of the LXR agonist on our selected epididymal genes is unlikely to be a consequence of its sequestration outside of the epididymis territory, but rather reflects that these genes are not directly regulated by LXRs.

Histological analyses of the caput epididymides of LXR $\alpha \beta$-deficient mice revealed a profound defect of the caput epithelium organization. Intriguingly, only the proximal regions (segments 1 and 2) of the caput epididymis epithelium were disrupted in the $\operatorname{LXR} \alpha \beta^{-/-}$-null mice, while the more distal regions of the caput (segments 3 to 5) as well as the efferent ducts, the corpus and the cauda epididymides remained undisturbed. Looking at the caput epididymides of LXR $\alpha \beta^{-/-}$mice of various ages, we noticed that the first signs of the epithelium defect started within segment 2 of the caput and then subsequently reached the more proximal part of the organ (i.e. segment 1 of the caput). These observations suggested that the epithelial cells of the proximal caput segment 2 are the primary targets of the oxysterol receptors in the adult mouse epididymis. The epithelium defect resulted in a complete regression of the highly polarized columnar-type secretory epithelium. Such a localized disruption of the caput epithelium argues in favour of a specific role of LXRs in the maintenance of the differentiated state of the caput epididymides.

Beside the disruption of the organization of the caput epithelium in LXR $\alpha \beta^{-/-}$mice, spermatozoa recovered from these mice were scarce and exhibited structural fragility. Using classical protocols for cauda epididymis sperm retrieval, spermatozoa collected from LXR $\alpha \beta$-deficient mice were broken at the sperm midpiece level. In addition, isolated flagella were either bent or angulated in most cases. It is interesting to note that several mouse models of epididymal dysfunction leading to male infertility have been recently reported and that each model exhibited a similar sperm tail phenotype. This is the case of the c-ros knockout mice, a caput-expressed tyrosine kinase receptor resembling the epidermal growth factor receptor (Sonnenberg-Riethmacher et al. 1996). The RXR $\beta$ knockout mouse model (Kastner et al. 1996) and, very recently, the apolipoprotein E receptor-2 knockout mouse model (Andersen et al. 2003) also showed a similar phenotype. In a different context, hairpin tail morphology of sperm flagella has been reported for the GPX5-Tag2 transgenic mouse model in which the promoter of the GPX5 gene was used to overexpress the SV40 large- $T$ antigen in the mouse caput epididymidis (Sipila et al. 2002). Interestingly, in at least two of these mouse transgenic contexts (c-ros and GPX5Tag2), the sperm flagella structural defect was correlated with structural abnormalities in the caput epididymal epithelium. It was proposed that these changes in the caput epithelium resulted in impaired secretory and/or reabsortive functions of the caput, ultimately affecting sperm volume regulation (Sonnenberg-Riethmacher et al. 1996, Yeung et al. 1998, 1999, 2002, Sipila et al. 2002). In these transgenic models, either a small territory of the caput was absent (c-ros knockout model; Sonnenberg-Riethmacher et al. 1996) or a mild proliferation of the caput epithelium was seen (GPX5-Tag2 and MMTV-RARal transgenic models; Costa et al. 1997, Sipila et al. 2002). In our LXR $\alpha \beta$ knockout model, we observed a drastic change in the structure of the proximal caput epithelium (segments 1 and 2 of the caput). There was neither loss of territory nor drastic variation in the proliferation of epithelial cells. These different models once again suggest that the caput epididymidis and especially its very first segments (initial segment 1 and 2) as a very critical region for the acquisition of spermatozoa fertilizing ability. For the RXR $\beta$ knockout model, it has been suggested that accumulation of lipids in the 
epididymal ducts could be in part responsible for the sperm defect (Kastner et al. 1996). An abnormally dense ductal fluid suspected to block the epididymal lumen was also reported for transgenic mice expressing a dominant negative mutant of RAR $\alpha$ (Costa et al. 1997). Since RXRs are the heterodimeric partners of LXRs, we would expect to observe similar accumulations of lipids in the epididymis of LXR $\alpha \beta$-deficient mice. Oil-red $\mathrm{O}$ staining did not reveal strong luminal accumulations of lipidic materials in the epididymal tubules of the 10-month-old LXR $\alpha \beta^{-/-}$animals. However, oil-red $\mathrm{O}$ staining of the $\operatorname{LXR} \alpha \beta^{-/-}$ animals did reveal that lipidic inclusions are present within the caput epithelium, suggesting that lipidic transfer systems are impaired in the transgenic animals. In a similar way to that observed in the RXR $\beta$ knockout model, lipid metabolism was found to be impaired in the epididymis of mice deficient for apoB gene expression (Huang et al. 1996), apoER2 gene expression (Andersen et al. 2003) or the acid sphingomyelinase gene (Butler et al. 2002). ApoB, apo E and apoER2 (receptor 2 of apolipoprotein E) genes encode proteins that, together with ATP-binding cassette (ABC) transporters, are involved in the cellular export of cholesterol. Although not directly demonstrated at the molecular level, these genes could also be target genes for LXRs which act as modulators of cholesterol homeostasis: storage, synthesis, as well as reverse transport and export (Peet et al. 1998a,b). Interestingly, spermatozoa phenotypes observed in the different knockout models reported above go from the appearance of hairpin structures on the flagella of various proportions of cauda spermatozoa (Hurst et al. 2001, Butler et al. 2002, Sipila et al. 2002) to a partial disorganization of the sperm midpiece mitochondrial compartment (Kastner et al. 1996, Andersen et al. 2003). In the LXR $\alpha \beta$-deficient animals too, the main defect seems to concern the sperm midpiece since all the sperm cells that we have retrieved from the cauda epididymides of adult animals aged 12 months exhibited a structural fragility resulting in the breakage of the sperm midpiece. In addition most isolated flagella were either bent or in a hairpin configuration resembling the different defects indicated above.

Whether the disruption of the caput epithelium is due to the fact that LXRs directly participate in the maintenance of the differentiated state of this highly specialized epithelium remains to be investigated. However, the distribution of $\operatorname{LXR} \alpha$ which was found to be preferentially expressed in the caput, together with the proximal caput localization of the epithelium abnormality in the LXR $\alpha \beta$-deficient mice argue in favour of a participation of LXRs in caput differentiation and function. At this stage, we cannot exclude the possibility that the caput defect in LXR $\alpha \beta$ knockout animals may be a consequence of changes in testicular activity. For example, it is well documented that androgens play a prominent role in the proper differentiation of the epididymis epithelium, which is completed postnatally at the onset of sexual maturity. Bilateral orchidectomy of adult male rats resulted in a rapid regression of the epididymis size as well as in regression plus de-differentiation of the epididymis epithelium (Moore \& Bedford 1979a). In castrated animals, the effects of androgen deficiency were essentially a decrease in the height of the principal cells along with structural subcellular changes such as the disappearance of vesicles from the cell apex, a reduction in rough endoplasmic reticulum and an increase in lysosome content. These features are indicative of inhibition of secretory function (Moore \& Bedford 1979b). However, the entire epididymis (caput and cauda) of castrated animals was affected by the changes while the defects we observed in our LXR $\alpha \beta^{-/-}$model concerned only caput segments 1 and 2 . Furthermore, while androgen deficiency was followed by a reduction in epididymis size, we observed in our model an overall increase in the size of the caput and an enlarged luminal compartment filled up with amorphous substances. These features are much more in line with problems in the reabsortive/ secretory functions of the epididymis epithelium. In addition, our observation that androgen supplementation did not restore the caput aspect in any way is not in favour of a prominent role exerted by decreasing testicular androgen levels in the setting up of this phenotype. It is however possible that our androgen supplementation was performed too late in the development of the phenotype to be effective. This point is currently under investigation. Beside androgens, it has been reported that the proximal regions of the epididymis are partly controlled by paracrine factors arriving along with the testicular fluid (Rigaudière et al. 1992, Hinton et al. 1998, Lan et al. 1998). Differences in the composition of testicular fluid might be responsible for the defects 
we observed in our model. Answers to this question will have to await a detailed analysis of the testes and testicular activities of the different LXR knockout models.

One final interesting fact arising from our observations of the epididymides of LXR $\alpha \beta$ mutant animals is that the epididymis and sperm defects take place quite abruptly at a relatively advanced age (around 6 months of age). At this point in our studies it is difficult to understand why the tissue abnormalities of the epididymis caput occurred at this particular age and settled in so rapidly, since this age does not correlate with any particular known physiological event. However, the late occurrence of the abnormalities together with the observation that sexually mature mice of a younger age (between 2 and 6 months) do not show dramatic fertility losses suggest that for a while compensatory phenomena take place to back up the absence of nuclear oxysterol receptors. In order to understand the role of LXRs in reproductive tissues and particularly in the caput epididymis we have undertaken a search for LXR epididymal target genes. In conclusion, these data point to a new role for nuclear oxysterol receptors in the regulation of epididymis territories and genes involved in male fertility.

\section{Acknowledgements}

The authors would like to thank Mrs Sophie Monceau, Christine Puchol and Sandrine Plantade for expert technical assistance in breeding the transgenic animals. Studies were funded by the CNRS and the French Ministry of Sciences and Technologies. J-M A L is supported by the Fondation pour la Recherche Médicale and the Fondation BNP-Paribas. D J M is an investigator of the Howard Hughes Medical Institute.

\section{References}

Abou-Haila A \& Fain-Maurel MA 1984 Regional differences of the proximal part of mouse epididymis: morphological and histological characterization. Anatomical Record 209 197-208.

Andersen OM, Yeung CH, Vorum H, Wellner M, Andreassen TK, Erdmann B, Mueller EC, Herz J, Otto A, Cooper TG \& Willnow TE 2003 Essential role of the apolipoprotein E receptor-2 in sperm development. Fournal of Biological Chemistry 278 23989-23995.

Britan A, Lareyre JJ, Lefrançois-Martinez AM, Manin M, Schwaab V, Greifeuille V, Vernet P \& Drevet JR 2004 Spontaneously immortalized epithelial cells from mouse caput epididymidis. Molecular and Cellular Endocrinology (In Press).

Butler A, He X, Gordon RE, Wu HS, Gatt S \& Schuchman EH 2002 Reproductive pathology and sperm physiology in acid sphingomyelinase-deficient mice. American Fournal of Pathology 161 1061-1075.

Costa SL, Boekelheide K, Vanderhyden BC, Seth R \& McBurney MW 1997 Male infertility caused by epididymal dysfunction in transgenic mice expressing a dominant negative mutation of retinoic acid receptor alpha 1. Biology of Reproduction 56 985-990.

Cross NL 1998 Role of cholesterol in sperm capacitation. Biology of Reproduction 59 7-11.

Drevet JR, Skeiky YAW \& Iatrou K 1994 GATA-type zinc finger motif-containing sequences and chorion gene transcription factors of the silkworm Bombyx mori. Fournal of Biological Chemistry $\mathbf{2 6 9}$ 10660-10667.

Drevet JR, Lareyre JJ, Schwaab V, Vernet P \& Dufaure JP 1998 The PEA3 protein of the Ets oncogenic family is a putative transcriptional modulator of the mouse epididymis-specific glutathione peroxidase gene, gpx5. Molecular Reproduction and Development 49 131-140.

Faure J, Ghyselinck NB, Jimenez C \& Dufaure JP 1991 Specific distribution of messenger ribonucleic acids for $24 \mathrm{kDa}$ proteins in the mouse epididymis as revealed by in situ hybridization: developmental expression and regulation in the adult. Biology of Reproduction 44 13-22.

Ghyselinck NB, Dufaure I, Lareyre JJ, Rigaudière N, Mattéi MG \& Dufaure JP 1993 Structural organization and regulation of the gene for the androgen-dependent glutathione peroxidase-like protein specific to the mouse epididymis. Molecular Endocrinology 7 258-272.

Haidl G \& Opper C 1997 Changes in lipids and membrane anisotropy in human spermatozoa during epididymal maturation. Human Reproduction 12 2720-2723.

Hinton BT, Lan ZJ, Rudolph DB, Labus JC \& Lye RJ 1998 Testicular regulation of epididymal gene expression. Fournal of Reproduction and Fertility 53S 47-57.

Huang LS, Voyiaziakis E, Chen HL, Rubin EM \& Gordon JW 1996 A novel functional role for apolipoprotein B in male infertility in heterozygous apolipoprotein B knockout mice. PNAS 93 10903-10907.

Hurst R, Korytowski W, Kriska T, Esworthy RS, Chu FF \& Girotti AW 2001 Hyperresistance to cholesterol hydroperoxide-induced peroxidative injury and apoptotic death in a tumor cell line that overexpresses glutathione peroxidase isotype-4. Free Radical Biology and Medicine 31 1051-1065.

Jimenez C, Ghyselinck NB, Depeiges A \& Dufaure JP 1990 Immunochemical localization and association with spermatozoa of androgen-regulated proteins of MR 24000 secreted by the mouse epididymis. Biology of the Cell 68 171-174.

Kastner P, Mark M, Leid M, Gansmuller A, Chim W, Grondona JM, Decimo D, Krezel W, Dierich A \& Chambon P 1996 Abnormal spermatogenesis in RXR $\beta$ mutant mice. Genes and Development 10 80-92.

Komuves LG, Schmuth M, Fowler AJ, Elias, PM, Hanley K, Man MQ Moser AH, Lobaccaro JM, Williams ML, Mangelsdorf DJ \& Feingold KR 2002 Oxysterol stimulation of epidermal differentiation is mediated by liver $\mathrm{X}$ receptor-beta in murine epidermis. Fournal of Investigative Dermatology 118 25-34.

Lan ZJ, Palladino MA, Rudolph DB, Labus JC \& Hinton BT 1997 Identification, expression, and regulation of the transcriptional factor polyomavirus enhancer activator 3 , and its putative role in regulating the expression of gamma-glutamyl transpeptidase mRNA-IV in the rat epididymis. Biology of Reproduction 57 186-193.

Lan ZJ, Labus JC \& Hinton BT 1998 Regulation of gamma-glutamyl transpeptidase catalytic activity and protein level in the initial segment of the rat epididymis by testicular factors: role of basic 
fibroblast growth factor. Biology of Reproduction 58 197-206.

Lan ZJ, Lye RJ, Holic N, Labus JC \& Hinton BT 1999 Involvement of polyomavirus enhancer activator 3 in the regulation of expression of gamma-glutamyl transpeptidase messenger ribonucleic acid-IV in the rat epididymis. Biology of Reproduction $\mathbf{6 0}$ $664-673$.

Lefrançois AM, Jimenez C \& Dufaure JP 1993 Developmental expression and androgen regulation of $24 \mathrm{kDa}$ secretory proteins by the murine epdididymis. International Fournal of Andrology $\mathbf{1 6}$ $147-154$.

Lillie RD \& Ashburn LL 1943 Supersaturated solutions of fat stains in dilute isopropanol for domonstration of actue fatty degenerations not shown by Herscheimer technique. Archives of Pathology 36 432-438.

Moore HD \& Bedford JM 1979a The differential absorptive activity of epithelial cells of the rat epididymus before and after castration. Anatomical Record 193 313-327.

Moore HD \& Bedford JM 1979b Short-term effects of androgen withdrawal on the structure of different epithelial cells in the rat epididymis. Anatomical Record 193 293-311.

Peet DJ, Janowski BA \& Mangelsdorf DJ 1998a The LXRs: a new class of oxysterol receptors. Current Opinion in Genetics and Development 8 571-575.

Peet DJ, Turley SD, Ma W, Janowski BA, Lobaccaro JM, Hammer RE \& Mangelsdorf DJ $1998 b$ Cholesterol and bile acid metabolism are impaired in mice lacking the nuclear receptor LXRalpha. Cell 93 693-704.

Repa JJ \& Mangelsdorf DJ 2000 The role of orphan nuclear receptors in the regulation of cholesterol homeostasis. Annual Review of Cell and Developmental Biology 16 459-481.

Repa JJ, Liang G, Ou J, Bashmakov Y, Lobaccaro JM, Shimomura I, Shan B, Brown MS, Goldstein JL \& Mangelsdorf DJ 2000 Regulation of sterol regulatory element-binding protein-lc gene (SREBP-1c) by oxysterol receptors, LXRalpha and LXRbeta. Genes and Development 14 2819-2830.

Rigaudiè ere N, Ghyselinck NB, Faure J \& Dufaure JP 1992 Regulation of the epididymal glutathione peroxidase-like protein in the mouse: dependence upon androgens and testicular factors. Molecular Cell Endocr 89 67-77.

Sambrook J, Fritsch EF \& Maniatis T 1989 Molecular Cloning: A Laboratory Manual, edn 2. Cold Spring Harbor: Cold Spring Harbor Laboratory.

Schwaab V, Faure J, Dufaure JP \& Drevet JR 1998 GPX3: the plasma-type glutathione peroxidase is expressed under androgenic control in the mouse epididymis and vas deferens. Molecular Reproduction and Development 51 362-372.

Sipila P, Cooper TG, Yeung CH, Mustonen M, Penttinen J, Drevet JR, Huhtaniemi I \& Poutanen M 2002 Epididymal dysfunction initiated by the expression of Simian Virus $40 \mathrm{~T}$-antigen leads to angulated sperm flagella and infertility in transgenic mice. Molecular Endocrinology 16 2603-2617.

Sonnenberg-Riethmacher E, Walter B, Riethmacher D, Godecke S \& Birchmeier C 1996 The c-ros tyrosine kinase receptor controls regionalization and differentiation of epithelial cells in the epididymis. Genes and Development 10 1184-1193.

Travis AJ \& Kopf GS 2002 The role of cholesterol efflux in regulating the fertilization potential of mammalian spermatozoa. Fournal of Clinical Investigation 110 731-736.

Venkatesvaran A, Repa JJ, Lobaccaro JM, Bronson A, Mangelsdorf DJ \& Edwards PA 2000 Human white/murine ABC8 mRNA levels are highly induced in lipid-loaded macrophages. A transcriptional role for specific oxysterols. Fournal of Biological Chemistry 275 14700-14707.

Vernet P, Rigaudiere N, Ghyselinck NB, Dufaure JP \& Drevet JR 1996 In vitro expression of a mouse tissue-specific glutathione peroxidase-like protein lacking the selenocysteine can protect stably transfected mammalian cells against oxidative damage. Biochemistry and Cell Biology 74 125-131.

Vernet P, Faure J, Dufaure JP \& Drevet JR 1997 Tissue and developmental distribution, dependence upon testicular factors and attachment to spermatozoa of GPX5, a murine epididymis-specific glutathione peroxidase. Molecular Reproduction and Development 47 87-98.

Volle DH, Repa JJ, Mazur A, Cummins CL, Val P, Henry-Berger J, Caira F, Veyssiere G, Mangelsdorf DJ \& Lobaccaro JMA 2004 Regulation of the aldo-keto reductase gene akrlb7 by the nuclear oxysterol receptor LXR $\alpha$ in the mouse intestine: putative role of LXRs in lipids detoxification processes. Molecular Endocrinology 18 888-898.

Yeung CH, Sonnenberg-Riethmacher E \& Cooper TG 1998 Receptor tyrosine kinase c-ros knockout mice as a model for the study of epididymal regulation of sperm function. Fournal of Reproduction and Fertility 53S 137-147.

Yeung CH, Sonnenberg-Reithmacher E \& Cooper TG 1999 Infertile spermatozoa of c-ros tyrosine kinase receptor knockout mice show flagellar angulation and maturational defects in cell volume regulatory mechanisms. Biology of Reproduction $\mathbf{6 1}$ 1062-1069.

Yeung CH, Anapolski M, Sipila P, Wagenfeld A, Poutanen M, Huhtaniemi I, Nieschlag E \& Cooper TG 2002 Sperm volume regulation: maturational changes in fertile and infertile transgenic mice and association with kinematics and tail angulation. Biology of Reproduction 67 269-275.

Received 1 July 2004

Accepted 14 July 2004 